\title{
Medicine Storage, Wastage and Associated Determinants Among Urban Households: A Systematic Review of Household Surveys
}

\author{
Adineh Jafarzadeh \\ Tabriz University of Medical Sciences \\ Alireza Mahboub-Ahari ( $\square$ aharia@tbzmed.ac.ir) \\ Tabriz University of Medical Sciences https://orcid.org/0000-0002-9170-2950 \\ Moslem Najafi \\ Tabriz University of Medical Sciences \\ Mahmood Yousefi \\ Tabriz University of Medical Sciences \\ Koustuv Dalal \\ Mid sweden University
}

\section{Research article}

Keywords: medicine, home storage, wastage, household, not in use, expired

Posted Date: October 14th, 2020

DOI: https://doi.org/10.21203/rs.3.rs-71586/v1

License: (9) (i) This work is licensed under a Creative Commons Attribution 4.0 International License. Read Full License

Version of Record: A version of this preprint was published at BMC Public Health on June 12th, 2021. See the published version at https://doi.org/10.1186/s12889-021-11100-4. 


\section{Abstract}

Background: Irrational household storage of medicines is a world-wide problem resulting medicine wastage and associated harms, which imposes an additional burden on the health care system. The study has performed a systematic review of household surveys to provide strong evidences and policy implications through a comprehensive and comparative understanding of available global literatures. The review also maps existing literature on the burden, outcomes and affecting socio-economic factors of medicine storage and wastage.

Methods: Five electronic databases were searched (from inception to 2019) for surveys that reviewed in-home medicine storage modality, size, cost and main determinants. The methodological quality of included studies was appraised through an adapted checklist developed by past studies.

Results: From the initial 2604 records we identified, 22 studies met our inclusion criteria. In 16 studies, medicine storage rates were reported for more than $70 \%$. The maximum rate of potential (not in use medicines) and real (expired or without expiration date medicine) wastage were about 70 and 40 percent, respectively. The most common classes of medicines found in households belonged to the nervous system (18\%) and anti-infective for systemic use (15\%). Income, education, age, presence of chronic illness, female gender and insurance coverage were among the factors influencing medicine storage. The most commonly used method of disposal was throwing them in the garbage.

Conclusions: Factors beyond medical needs determined medicine storage in the studied contexts which urges effective strategies in the supply and demand side of the medicine consumption chain. The first necessary step to mitigate home storage is adequate legislation and strict enforcement of regulations on dispensing, prescription and marketing of medicines. Patient pressure on excessive prescription, irrational storage and use of medicines deserve efficient community centered programs for increasing awareness of these issues. Hazardous consequences of inappropriate disposal should be mitigated by different take back programs, particularly in low and middle income countries.

\section{Background}

Home storage of medicines is a worldwide health problem that can occur because of improper utilization of medicines and/or nonadherence with drug therapy [1-5]. During past years, medicine utilization pattern has changed, leading to greater purchasing volumes and, excessive accumulation at home [6]. According to the World Health Organization (WHO) more than 50\% of medicines are prescribed and dispensed inappropriately, which cause unnecessary storage. [7] Medicines availability at home provokes irrational use of medicines and associated risks such as adverse drug events, accidental intoxication, disease concealment, drugdrug reaction, antibiotic resistance and finally economic loss [8-12]. Seventy-five percent of unintentional poisonings in the United States have occurred due to improper storage of drugs at home [13]. Storage medicine in unsuitable places also triggers medicine wastage which imposes an economic burden on households, the health sector and the society [14-16]. According to Siler et al., $40 \%$ of prescription drugs in the United States never actually used instead are either expired or thrown away [17].

By review of medicine chain, it can be clarified that the problem starts with over prescription by health professionals [18-20], continues through improper decisions such as over-purchasing [6], non-adherence with medicine $[19,21,22]$ and drug saving for future usage $[3,23,24]$ and lasts with medicine wastage and its negative consequences [14, 25-28].

several systematic reviews have been conducted for assessment of different aspects of the medicine supply and consumption chain, for example, self-medication practice [29-36], medicine wastage [37, 38] and disposal of unused medication [39, 40]. All of them attempted to determine the burden of the problem to households and society in terms of health-related risks and environmental or fiscal measures. Only one systematic review has investigated medicine home storage as a prior stage for wastage, selfmedication and associated risks. [41]. Hussein et al (2016) have systematically reviewed related literature to study trends and practices in medicine storage; the last date of the study search was 2016. The authors included nine eligible studies then descriptively presented the storage and disposal pattern, types of stored medicine by drug name and associated risks of inappropriate storage and disposal of medicines. Finally, researchers qualitatively listed affecting factors without supporting the effect size and significance measures [41]. Considering the importance of socio-economic determinants of medicine storage and wastage, we conducted the current systematic review to map existing evidence on the size and modality of stored medicine both individually and according to the Anatomical Therapeutic Chemical (ATC) classification [42]. Such evidence could inform future 
researches on this field. Together with, we fully scrutinized the household surveys who estimated socio-economic determinants of storage and wastage of medications through econometric models all around the world. The results of this part of the study can provide comprehensive evidence for planning and management strategies to mitigate the problem.

\section{Method}

\section{literature search procedure}

This review was carried out according to the Preferred Reporting Items for Systematic Reviews and Meta-Analyses (PRISMA) statement [43], and applying the PRISMA checklist (Additional file 1). PubMed, EMBASE, OVID, SCOPUS, ProQuest, and Google scholar were sought from inception to February 2016. All of the keywords were in English and the search strategy was restricted to English language publications. The terms used in this review were informed using a recent systematic review [37] and expanded based on co-author agreement (Additional file 2). The electronic search was complemented by hand-searching of related articles and the reference lists of final studies. The research update was conducted using the same strategy in February 2019. Editorials, commentaries and opinion pieces were all excluded. To find full-texts or inaccessible English versions, email contact was made by the authors. Due to the heterogeneity of papers, a meta-analysis was not performed and the results of studies are presented descriptively.

\section{Requirements for inclusion}

Screening of studies was conducted by two reviewers (AM\&AJ), who reviewed studies independently. Initially, the titles and abstracts of studies were screened. Full texts were investigated for eligibility related reports. Disagreements were resolved by helping a third reviewer (MN). All population based household surveys which met following criteria were included in this systematic review: 1) study explicitly identified medicine storage and its determinant factors among households or individuals, 2) study reported quantitative survey data about this review's main questions, and 3) study published in or translated into English. Where papers included both urban and rural households, results were extracted for urban households. Studies reporting solely medicine wastage in terms of the proportion of households than medicine were excluded. Studies focusing solely on a specific medicine or population subgroup were excluded. Finally, several studies were excluded because they were not a household survey and the source of data collection was pharmacies of occasional charity campaigns.

\section{Extraction of items}

Two reviewers (AM\&AJ) extracted the following data from studies: the country where the study was conducted, year of publication, description of households included, sampling techniques, sample size, data for storage rate and place, medicine type, amount, category, method of disposal and numerical data for key determinants of medicine storage and wastage. The extracted data for inhome medicines were classified according to the first level of the ATC classification. For studies not reporting their results in terms of ATC classification, the researchers classified both individual medicine or any reported category, based on the Guidelines for ATC Classification and Daily Dose Defined (DDD) assignment (2018) [42]. The real wastage (expired or without expiration date) as well as the potential wastage (not in used medicine) was measured separately.

\section{Outcomes}

To answer the study question, following outcomes were selected: medicine storage rate (as a percentage of households), medicine per household, real medicine wastage, potential medicine wastage, category of medicines, category of wastage medicine, the frequency of individual medicine, factors associated with storage and wastage medicine, cost of wastage medicines, dosage forms of medicine, storage place and disposal method were reviewed.

\section{Quality assessment}

The methodological quality of eligible studies was assessed using an adapted version of the quality assessment checklist which had been developed and used by West et al [37]. The researchers rated each question by giving the following answers Yes, No, Partial, Not applicable, or Unclear.

\section{Results}




\section{Literature search and eligible studies}

Figure 1 provides information on the number of identified articles. From a total of 2604 initially identified citations, 578 were duplicates and 1991 did not meet the inclusion criteria. Finally, 35 full texts were fully scrutinized, of which 13 were excluded because of the lack of relevance, and 22 were recognized as eligible for final review. A study was excluded because it was conducted in a rural area [44]. Although two articles papers studied both urban and rural population, we were not able to separate results for urban subjects $[1,45]$. Study by Wongpoowarak et al., reported only medicine wastage without providing data for storage modalities and its determinants [46]. Three studies were excluded because they had reported medicine storage in terms of the household than medicine $[28,47,48]$. Two studies were non-English [49, 50], 2 studies addressed a specific medicine [51, 52] and 2 studies were focused on a particular population subgroup $[53,54]$.

\section{Characteristics of studies}

All the studies were cross-sectional and used a questionnaire for gathering the relevant data from the study subjects. Two studies investigated both urban and rural household to assess medicine wastage but only urban household data was extracted [26, 55]. A total of 12750 households were included across the 22 studies from 2002 to 2019 . The majority of studies were published from 2010 onwards $(n=18,82 \%)$. The sample sizes varied within the studies included in this review. The lowest sample size was 102 households, whilst the highest sample size was 2600 (Table 1). The majority of studies were from the Asia and Africa although there was a wide range of geographical locations including Nigeria: 2, Jordan: 1, Saudi Arabia and Persian Gulf Countries: 1, Tanzania: 1, Iraq: 1, India: 4, Sudan: 1, Palestine: 1, Thailand: 1, Iran: 1, Serbia: 3, Uganda: 1, Pakistan: 1, Indonesia: 1 and Ethiopia:1.

\section{Methodological quality}

The quality assessment is summarized in Fig. 2. No articles were excluded based on quality appraisal. All the studies were population-based and they covered a total of 12750 households. Most studies presented an appropriate sampling method as probability sampling was used much more often $(72.7 \%, n=16)$ than nonprobability sampling $(27.2 \%, n=6)$. Most studies had good congruity between the research methodology and their research question, data collection, data analysis and interpretation of results so most studies were of good quality. The objectives were clearly stated and, in most studies, the results were well reported $(86.3 \%, \mathrm{n}$ =19). Rate of wastage was explicitly reported in only three studies. However, for the rest, data were extracted according to the method which was introduced by Zargarzadeh et al [56]. None of the studies found a conflict of interest and in less than half of them, ethical approval was reported.

\section{Stored medicines: Storage rates and frequency of medicines}

According to the findings (Table 1), the prevalence of medicine storage ranged from 35.1\% [19] to 100\% [2]. Sixteen studies reported more than $70 \%$ prevalence rate, which half of them was at least $90 \%$. Tablets was the most common form (over $60 \%$ ) of medicines stored at home $[2,19,24,26,57,58]$. while syrup/ suspensions and capsule were ranked second and third, respectively $[22,24,26$, 57-59]. Only six studies, had classified their results by ATC and for the rest of them, we classified reported products according to WHO's a guideline (see Additional file 3). The most widely stored medicines were Nervous system (category N; $18 \%$ ), followed by Anti-infective for systemic use ( $\mathrm{J} ; 15 \%)$, Alimentary tract drug (A; $14 \%)$, Cardiovascular system (C; $10 \%)$, Respiratory system (R; $9 \%)$, musculoskeletal system ( $M ; 7 \%)$, Antiparasitic products, insecticides and repellents (P; $4 \%)$, Blood and blood forming organs (B; $3 \%)$, and Dermatological agents (D; 3\%) (Fig. 3). How to achieve the rank of the classes is given in Additional file 4. Frequency of individual medicines was reported in 4 studies with a total of 2371 households $[19,22,60,61]$. The most common individual medicine product was Paracetamol $(\mathrm{N} ; 9.6 \%)$, followed by Amoxicillin $(\mathrm{J} ; 6 \%)$, Diclofenac $(\mathrm{M} ; 4.6 \%)$ and Metronidazole $(\mathrm{J} ; 3.2 \%)$. The mean number of medicines stored per household, varied from 1.6 [24] to 23 [56] (Table 1). 
Table 1 Extracted study characteristics.

\begin{tabular}{|c|c|c|c|c|c|c|}
\hline Author, year & Country & $\begin{array}{l}\text { Sample } \\
\text { size }\end{array}$ & $\begin{array}{l}\text { Recall Period } \\
\text { (Month) }\end{array}$ & $\begin{array}{l}\text { Medicines per } \\
\text { Household }\end{array}$ & $\begin{array}{l}\text { Potential } \\
\text { Wastage (\%) }\end{array}$ & $\begin{array}{l}\text { Real } \\
\text { Wastage (\%) }\end{array}$ \\
\hline $\begin{array}{l}\text { Abou-Auda 2002, } \\
\text { [21] }\end{array}$ & Saudi Arabia & 1554 & In 2001 & $8 \pm 4.3$ & 4.26 & 25.8 \\
\hline $\begin{array}{l}\text { Abou-Auda 2002, } \\
\text { [21] }\end{array}$ & $\begin{array}{l}\text { Persian Gulf } \\
\text { Countries }\end{array}$ & 87 & In 2001 & 7.1 & - & 41.3 \\
\hline $\begin{array}{l}\text { Abushanab et al } \\
\text { 2013, [61] }\end{array}$ & Jordan & 243 & 6 & $10.9 \pm 5.2$ & 69 & 12.75 \\
\hline $\begin{array}{l}\text { B Banwat et al 2016, } \\
\text { [57] }\end{array}$ & Nigeria & 130 & - & 4.8 & 65.8 & 0.1 \\
\hline $\begin{array}{l}\text { Dayom DW et al } \\
2014,[24]\end{array}$ & Nigeria & 300 & - & 1.6 & - & 39 \\
\hline $\begin{array}{l}\text { Deviprasad et al } \\
\text { 2016, [58] }\end{array}$ & India & 114 & 2 & 1.62 & $9 \%$ & 9 \\
\hline Gitawati 2014, [62] & Indonesia & 250 & 1 & 4.9 & 69.2 & - \\
\hline $\begin{array}{l}\text { Gupta et al 2011, } \\
\text { [63] }\end{array}$ & India & 102 & 6 & NR & - & 26 \\
\hline Jassim 2010, [3] & Iraq & 300 & $2007-2008$ & 14.26 & 55.2 & 13.36 \\
\hline $\begin{array}{l}\text { JUSTIN et al 2002, } \\
\text { [64] }\end{array}$ & Tanzania & 400 & - & 1.9 & 35.3 & - \\
\hline $\begin{array}{l}\text { Hussain et al 2019, } \\
\text { [2] }\end{array}$ & Pakistan & 900 & & 2.94 & 79.6 & - \\
\hline $\begin{array}{l}\text { Kusturica et al,2012, } \\
\text { [55] }\end{array}$ & Serbia & 108 & 6 & 11.3 & 16.7 & 10.3 \\
\hline $\begin{array}{l}\text { Kumar et al 2013, } \\
\text { [65] }\end{array}$ & India & 500 & 6 & 4 & 28.5 & 1.56 \\
\hline $\begin{array}{l}\text { Kusturica et al 2016, } \\
\text { [66] }\end{array}$ & Serbia & 1008 & over 8 & 11.4 & - & 9.2 \\
\hline $\begin{array}{l}\text { Martin s et al 2017, } \\
\text { [15] }\end{array}$ & Brazil & 267 & 2 & $3.7 \pm 2.1$ & 38.4 & 5.7 \\
\hline $\begin{array}{l}\text { Mirza et al 2016, } \\
\text { [26] }\end{array}$ & India & 400 & $2012-2014$ & $5.11 \pm 3.42$ & 38 & 2.94 \\
\hline Ocan et al 2014, [19] & Uganda & 892 & 2 & $6 \pm 5$ & 51.8 & - \\
\hline $\begin{array}{l}\text { Ristic et al 2016, } \\
{[67]}\end{array}$ & Serbia & 2600 & 6 & 8.2 & 56.3 & 12.22 \\
\hline $\begin{array}{l}\text { Sooksriwong et al } \\
2013,[68]\end{array}$ & Thailand & 357 & 3 & 6.1 & 34 & 3.7 \\
\hline $\begin{array}{l}\text { Sweileh et al 2010, } \\
\text { [22] }\end{array}$ & Palestine & 465 & 2 & $13.3 \pm 7.8$ & 33.8 & 28.7 \\
\hline Teni et al 2017, [60] & Ethiopia & 771 & 1 & $1.85 \pm 1$ & 41.1 & 3.14 \\
\hline $\begin{array}{l}\text { Yousif et al 2002, } \\
\text { [59] }\end{array}$ & Sudan & 469 & 2 & 4.4 & 47.2 & 18.2 \\
\hline $\begin{array}{l}\text { Zargarzadeh et al } \\
2005,[56]\end{array}$ & Iran & 533 & 6 & $22.99 \pm 20.1$ & 53.8 & 38.8 \\
\hline
\end{tabular}


Out of 22 studies, only $18[3,15,21,22,24,26,55-61,63,65-68]$ had reported real and $19[2,3,15,19,21,22,26,55-62,64,65,67$, $68]$ had reported potential rate of medicine wastage. According to the results, the potential rate of wastage was reported from 4.26[21] to 69.2\% [62], and the real rate of wastage was from 0.1[57] to 41.3\% [21] (Table 1). How to calculate the potential waste for different studies is given in Additional file 5. Anti-infective medicines (category $\mathrm{J}$ ) had the first rank among both wastage types (Fig. 3) (see Additional file 6 and 7).

\section{The effect of Patient-related factors on medicine storage and wastage}

Seven studies $[2,19,22,56,58,60,61]$ involving 3918 households performed statistical analysis however a limited number of them reported their results by odds ratios (Table 2 ). The commonly reported factors that determined medicine storage included: income $[19,56,60,61]$, education $[22,56,61]$, age $[2,58]$, family size $[22,61]$, presence of chronic illness $[22,56,60]$, female genders [19, 58], past successful treatment [19], working members [61], presence of healthcare worker in the household [58, 61], insurance coverage $[22,56]$ (Table 2). The association between medicine wastage with patient-related factors was analyzed by 4 studies $[3,21,24,66]$ highlighting that family size [66], children under 12 age [66], education [3, 24], unemployed [24], per capita medical expenditure [21] were significantly associated with medicine wastage (Table 3).

Cost

The monetary value of wasted medicines was reported by 6 studies highlighting that between $10 \%$ and $50 \%$ of medicines belong to the wasted medicines. The study by Abou-Auda reported the value of wasted medicine for Saudi Arabia and the other Persian Gulf countries separately [21]. However, this represents only a fraction of the wasted medicines at home, and the actual value of the wasted medicines is certainly greater than this (Table 4).

\section{Conditions of storage}

According to a guideline from WHO [69], the appropriate storage condition is keeping the medicines in out of reach places for children, for example, a cabinet or refrigerator which can protect them from being affected by environmental factors such as heat, humidity, light, and dust. Storage conditions of medicines were addressed in seven studies involving 3148 households [3, 22, 59-61, $64,65]$. Results showed that a considerable amount of household medicines did not have appropriate storage conditions. Regarding the results of the studies, only about $40-60 \%$ of the medicines were in appropriate condition $[3,22,59,61,65]($ Fig. 4). 
Table 2 The effect of Patient-related factors on medicine storage.

\begin{tabular}{|c|c|c|c|c|}
\hline \multirow[t]{2}{*}{ Variables } & \multirow[t]{2}{*}{ Study } & \multirow[t]{2}{*}{$\begin{array}{l}\text { association ( } \mathrm{P}- \\
\text { value) }\end{array}$} & \multicolumn{2}{|l|}{ Odds ratio } \\
\hline & & & UOR (95\%Cl) & AOR $(95 \% \mathrm{Cl})$ \\
\hline \multirow[t]{5}{*}{ Income } & Teni et al 2017,[60] & $\uparrow(<0.05)$ & & $\begin{array}{l}2.518[1.215- \\
5.221]\end{array}$ \\
\hline & Ocan et al 2014,[19] & $\uparrow$ & $\begin{array}{l}1.76[1.19- \\
2.61]\end{array}$ & \\
\hline & $\begin{array}{l}\text { Zargarzadeh et al 2005, } \\
\text { [56] }\end{array}$ & $\uparrow(0.002)$ & & \\
\hline & $\begin{array}{l}\text { Abushanab et al 2013, } \\
\text { [61] }\end{array}$ & $\uparrow(0.034)$ & & \\
\hline & Sweileh et al 2010,[22] & NS (0.076) & & \\
\hline \multirow[t]{3}{*}{ insurance coverage } & $\begin{array}{l}\text { Zargarzadeh et al 2005, } \\
\text { [56] }\end{array}$ & $\uparrow(0.002)$ & & \\
\hline & Sweileh et al 2010,[22] & $\uparrow(0.01)$ & & \\
\hline & $\begin{array}{l}\text { Abushanab et al 2013, } \\
\text { [61] }\end{array}$ & NS & & \\
\hline \multirow[t]{3}{*}{ Family size } & Sweileh et al 2010,[22] & $\uparrow(0.001)$ & & \\
\hline & $\begin{array}{l}\text { Abushanab et al 2013, } \\
\text { [61] }\end{array}$ & $\uparrow(0.004)$ & & \\
\hline & $\begin{array}{l}\text { Zargarzadeh et al 2005, } \\
\text { [56] }\end{array}$ & NS & & \\
\hline \multirow[t]{4}{*}{ Presence of chronic illness } & Sweileh et al 2010,[22] & $\uparrow(0.019)$ & & \\
\hline & $\begin{array}{l}\text { Zargarzadeh et al 2005, } \\
\text { [56] }\end{array}$ & $\uparrow(<0.001)$ & & \\
\hline & Teni et al 2017,[60] & $\uparrow(<0.05)$ & & $\begin{array}{l}14.824[9.072- \\
24.2]\end{array}$ \\
\hline & $\begin{array}{l}\text { Abushanab et al 2013, } \\
\text { [61] }\end{array}$ & NS & & \\
\hline \multirow[t]{2}{*}{ Female gender } & Ocan et al 2014,[19] & $\uparrow$ & $0.63[0.5-0.9]$ & \\
\hline & $\begin{array}{l}\text { Deviprasad et al 2016, } \\
\text { [58] }\end{array}$ & $\uparrow(0.01)$ & & $0.22[0.07-0.7]$ \\
\hline Past successful treatment & Ocan et al 2014,[19] & $\uparrow$ & $\begin{array}{l}1.3[0.95- \\
1.77]\end{array}$ & \\
\hline Working members & $\begin{array}{l}\text { Abushanab et al 2013, } \\
\text { [61] }\end{array}$ & $\uparrow(0.003)$ & & \\
\hline \multirow[t]{5}{*}{ Education } & Sweileh et al 2010,[22] & $\uparrow(0.01)$ & & \\
\hline & $\begin{array}{l}\text { Abushanab et al 2013, } \\
\text { [61] }\end{array}$ & $\uparrow(<0.001)$ & & \\
\hline & $\begin{array}{l}\text { Zargarzadeh et al 2005, } \\
\text { [56] }\end{array}$ & $\uparrow(0.003)$ & & \\
\hline & Teni et al 2017,[60] & NS & & \\
\hline & Hussain et al 2019,[2] & $\downarrow(0.03)$ & & \\
\hline
\end{tabular}




\begin{tabular}{|c|c|c|c|}
\hline \multirow[t]{3}{*}{ Occupation } & $\begin{array}{l}\text { Abushanab et al 2013, } \\
\text { [61] }\end{array}$ & NS & \\
\hline & $\begin{array}{l}\text { Zargarzadeh et al 2005, } \\
\text { [56] }\end{array}$ & NS & \\
\hline & Hussain et al 2019,[2] & $(0.002)$ & \\
\hline \multirow{5}{*}{$\begin{array}{l}\text { Presence of healthcare worker in } \\
\text { household }\end{array}$} & Teni et al 2017,[60] & NS & \\
\hline & $\begin{array}{l}\text { Deviprasad et al 2016, } \\
\text { [58] }\end{array}$ & $\uparrow(0.01)$ & $\begin{array}{l}7.22[1.52- \\
34.21]\end{array}$ \\
\hline & $\begin{array}{l}\text { Abushanab et al 2013, } \\
\text { [61] }\end{array}$ & $\uparrow$ & \\
\hline & $\begin{array}{l}\text { Zargarzadeh et al } 2005, \\
\text { [56] }\end{array}$ & $\downarrow(<0.001)$ & \\
\hline & Hussain et al 2019,[2] & $\mathrm{NS}(0.19)$ & \\
\hline \multirow[t]{2}{*}{ Age } & $\begin{array}{l}\text { Deviprasad et al } 2016, \\
\text { [58] }\end{array}$ & $\uparrow(0.03)$ & $\begin{array}{l}0.24[0.06- \\
0.89]\end{array}$ \\
\hline & Hussain et al 2019,[2] & $\uparrow(0.006)$ & $\begin{array}{l}1.017[1.005- \\
1.03]\end{array}$ \\
\hline \multirow[t]{3}{*}{ Children $\leq 6$ years } & $\begin{array}{l}\text { Zargarzadeh et al 2005, } \\
\text { [56] }\end{array}$ & NS & \\
\hline & $\begin{array}{l}\text { Abushanab et al } 2013 \text {, } \\
\text { [61] }\end{array}$ & NS & \\
\hline & $\begin{array}{l}\text { Deviprasad et al 2016, } \\
\text { [58] }\end{array}$ & NS & \\
\hline \multirow[t]{3}{*}{ Elderly $\geq 65$ years } & $\begin{array}{l}\text { Zargarzadeh et al 2005, } \\
\text { [56] }\end{array}$ & NS & \\
\hline & $\begin{array}{l}\text { Abushanab et al } 2013 \text {, } \\
\text { [61] }\end{array}$ & NS & \\
\hline & $\begin{array}{l}\text { Deviprasad et al 2016, } \\
\text { [58] }\end{array}$ & NS & \\
\hline
\end{tabular}

Table 3 The effect of Patient-related factors on medicine wastage 


\begin{tabular}{|lll|}
\hline Variables & Study & association (P-value) \\
\hline Family size & Kusturica et al 2016,[66] & $\uparrow(0.002)$ \\
\hline Children $\leq 12$ years & Dayom DW et al 2014,[24] & $\uparrow(\mathrm{NR})$ \\
\hline Education & Kusturica et al 2016,[66] & $\uparrow(0.019)$ \\
\hline & Kusturica et al 2016,[66] & $\uparrow(0.007)$ \\
\hline Unemployed & Jassim 2010,[3] & $\downarrow(p<0.01)$ \\
\hline & Dayom DW et al 2014, [24] & $\downarrow(N R)$ \\
\hline Elderly $\geq 65$ years & Hussain et al 2019,[2] & $\downarrow(N R)$ \\
\hline household per capita medical expenditure & Abou-Auda 2002,[21] & $\downarrow(p<0.001)$ \\
\hline NR: Not reported & Kusturica et al 2016,[66] & Ns (0.08) \\
\hline
\end{tabular}

Table 4

Cost of medicines (total and wasted).

\begin{tabular}{|c|c|c|c|c|c|}
\hline Author & Country & $\begin{array}{l}\text { Total cost of } \\
\text { medicines, (\$) }\end{array}$ & $\begin{array}{l}\text { Cost of wastage } \\
\text { medicines }(\$)\end{array}$ & $\begin{array}{l}\text { Wastage medicines based } \\
\text { on total number (\%) }\end{array}$ & $\begin{array}{l}\text { Wastage medicines } \\
\text { based on total cost (\%) }\end{array}$ \\
\hline \multicolumn{6}{|l|}{ All wastage } \\
\hline $\begin{array}{l}\text { Abou-Auda, } \\
\text { [21] }\end{array}$ & $\begin{array}{l}\text { Saudi } \\
\text { Arabia }\end{array}$ & $779,673,913$ & $149,697,391$ & 25.8 & 19.2 \\
\hline $\begin{array}{l}\text { Abou-Auda, } \\
\text { [21] }\end{array}$ & $\begin{array}{l}\text { Persian Gulf } \\
\text { Countries }\end{array}$ & 2,966 & 670 & 41.3 & 25 \\
\hline $\begin{array}{l}\text { Sweileh et al, } \\
\text { [22] }\end{array}$ & Palestine & 34,000 & 16,100 & 50.5 & 47.3 \\
\hline $\begin{array}{l}\text { Abushanab } \\
\text { et al, [61] }\end{array}$ & Jordan & 21,875 & 3,791 & 25 & 24.4 \\
\hline \multicolumn{6}{|l|}{ Real wastage } \\
\hline $\begin{array}{l}\text { Zargarzadeh } \\
\text { et al, [56] }\end{array}$ & Iran & 3,260 & 1,470 & 38.8 & 45 \\
\hline $\begin{array}{l}\text { Gupta et al, } \\
\text { [63] }\end{array}$ & India & 184 & 47.2 & 25.6 & 26 \\
\hline \multicolumn{6}{|c|}{ Potential wastage } \\
\hline $\begin{array}{l}\text { Sooksriwong } \\
\text { et al, [68] }\end{array}$ & Thailand & 12,000 & 1,100 & 9 & 9 \\
\hline
\end{tabular}

\section{The disposal method of medicine}

Of the 22 studies, six $[15,55,57,65-67]$ addressed the disposal practice among households. The most commonly used method of medicine disposal was throwing them in the garbage. According to the results of studies in Serbia [55, 66, 67], Nigeria [57], India [65], and Brazil [15], more than $80 \%$ of the households disposed of their medicines in the garbage. While medicine take-back program has globally known as a gold standard practice and has been conducted by many developed countries [70-74] but according to our results, the rate of households who adhering the take-back programs was reported from $0[57,65]$ to $8 \%[15]$ (Fig. 5). 


\section{Discussion}

This systematic review aimed to map the main findings of published surveys on medicine storage and key determinants among households. The majority of the articles are from Asia and Africa, three from Europe and one from South America, indicating medical storage and related wastage of resources are problems in Asia and Africa. The paucity of published papers in Europe and Oceania should not be attached to the ignorance of the problem in that region; however, this might be because of their drug take-back policies in the form of social campaigns or routine back to pharmacy strategies $[73,75-77]$. The present systematic review not only maps global evidence on the modality and causality of household medicine storage but also remarkably addresses possible solutions for dealing with the problem in different contexts.

Given that our systematic review only examined household surveys that quantitatively represent the problem from the consumer's perspective, the results should be treated with caution. Therefore, a deeper exploration of medicine storage reasons and consequences through qualitative study designs and from other stakeholder's perspectives (healthcare providers and decisionmakers) could be supplementary for our results.

A total of 12750 households were included from 22 household surveys. In 16 studies (72.7\%), more than $70 \%$ of households had medicine which half of them reported over $90 \%$ storage frequency. This high rate of storage raises the incidence of medicines wastage and its potential associated risks. Although in several countries medicine storage can be explained by disease pattern and health problems, for example, a high proportion (Gastrointestinal tract) GIT medicines in Jordan [61], malaria and anti-infective medicines in Tanzania [64], Iran [56], Ethiopia [60], Uganda [19] and Nigeria[24] and heart and diabetes medicines in Palestine [22], India [65] and Mexico [78], however in most of the countries the storage and consequently wastage are due to inappropriate prescription practice and inadequate patient adherence $[3,14,19,21,22,60,66,79]$.

Patient attitudes and social values are important contributing factors that stimulate medicine storage and wastage in different forms. According to the studies from Saudi Arabia, Kuwait, UAE, Qatar, Oman and India, patients gratify drug prescription as an outcome of their visit to public health facilities $[21,65]$. The role of patient attitudes has been confirmed by Hu J et al., and Norris $P$ et al., implying that immigrants from developing countries like China, India, Korea, Egypt and other Asian and African countries have different perceptions towards accessing and use of medicines which triggers irrational use of medicines [80, 81].

This review found evidence confirming that expired medicines were being used by households in low- and middle-income countries $[24,66]$. Dayum et al., has reported that more than $97 \%$ of Nigerian households used expired medicine or kept them for future use [24]. The same evidence either has been reported from high-income countries. [28, 82] In Australia, households stated that they used expired medicines either one year or longer, after expiration [82].

Based on the literature, to some extent medicine wastage is inevitable because of several reasons such as patient death, treatment failure, medicine change and side effects [37]. Then, to tackle medicine storage and wastage, smaller packages and shorter duration of prescriptions were endorsed as effective approaches by studies from both developed and developing countries $[3,56,60,62,64$, $77,83,84]$.

Paracetamol (Acetaminophen) belonging to group $\mathrm{N}$ was the most stored medicine among participated households. Although the finding is not surprising because paracetamol is the first-line treatment for pain and fever management $[2,22,57,61]$, however the availability, affordability, convenience, product marketing and misconception about its safety compared to NSAIDs (Non-steroidal anti-inflammatory drugs) has made the paracetamol family be the first choice of self-medication among people $[2,22,57,61,62]$. Despite a limited number of studies reported that keeping a limited stock of these medicines might be cost-saving due to lower physician visit $[3,26,62,63]$, but a much larger number of studies warned about the rising rate of self-medication, medicine wastage and its undesirable consequences [26, 85-87]. The second most widely stored medicines were group J (15\%). Antibiotics are the most known medicines in this group. Despite most health systems, antibiotics were licensed as prescription-only drugs, but they are easily purchased without a prescription $[3,19,21,26,56,62]$. The discrepancy between the legislation and daily practice, high expectation about antibiotics effectiveness, low awareness regard to antibiotic resistance and adverse events, high cost of physician consultation have cited as reasons for antibiotics storage [88-92]. The same evidence has been presented by Sawair et al., implying that patients visited the second physician because they did not receive antibiotics from the first physician [93]. 
According to results reported by included studies, categories $\mathrm{N}(18 \%), \mathrm{J}(15 \%)$, and $\mathrm{A}(14 \%)$, are the most stored medicines at home. This systematic review recognized a consistency between storage and wastage of these categories confirming the idea that medicine storage could potentially yield wastage. Inversely the category C, despite getting forth order among stored medicines, was not found among the first ranks of potential and real wasted drugs. Such discrepancies have been attributed to the prescription and dispensing policies by several studies as well as patient's better compliance with treatment by others $[2,3,56,60,65]$.

One of the main objectives of our systematic review was to study predicting factors of home storage of medicines, which can provide valuable evidence for designing and administering efficient health policies for mitigating the problem. Because of existing heterogeneity among the included studies, it was not possible to conduct a quantitative analysis of reported results. Thus the quantitative results of studies have narratively been synthesized. The results of the included studies showed that family size, number of employed members, level of education, health insurance coverage, being a woman, higher age group, economic state, presence of chronic illness, were associated with an increased number of home storage.

The positive association between home storage and wastage of medicine and household's purchasing power (higher income or lower prices) has also been confirmed by studies from high-income countries indicating that the problem is worldwide and factors beyond real health needs determine medicine demand and utilization $[28,76,94,95]$.

According to the findings of this study $[22,56]$, insurance was recognized as a positive motive for more storage as well as more wastage, suggesting that, although having medical insurance could financially protect household members against catastrophic health expenditures, but the lack of strict control on prescription, selling and demand of medicine could encounter entire health system to the rising cost of unnecessary storage and wastage of medicines. The presence or absence of medical insurance has been introduced as a stronger factor even than family income as a determinant of medicines stored at home $[22,56]$.

The impact of education on drug storage is interestingly different from that on wastage. Most of the literature reported a positive association between the level of education of the household's head and the amount of medicine storage [3, 22, 56, 59-61]. However, the number of medicine wastage was reported higher for illiterate or less educated counterparts $[2,3,24,59]$. It is obvious that education level prevents drug wastage through better compliance with the treatment or better storage practice $[3,19,22,26,59,61]$ but according to the studies, educated people also tend to purchase more medicines from retail pharmacies, store medicines for future use and are more prone to self-medication $[3,19,22,26,59,61]$.

there are significant differences between men and women in terms of medicine storage modality, amount and wastage. Notwithstanding the higher rate of in-home storage among women [19,58], the lower wastage rate was linked to households whose stored medicines were organized by female subjects [15]. Other studies have confirmed high storage rates among women $[15,95,96]$ with some reasons such as; gender-related physiopathology, lifestyle, contact to the health system and other biological differences such as pregnancy $[96,97]$. However other variations such as; women's tendency to excessive purchase and self-medication, lacks medical reasoning and can potentially be the focal point for improvement [98]. A study by Becker showed that wasted medicine was more frequently used by men than women [83].

To the best of our findings, there was a considerable variation in medicine storage place among studied countries, since the storage location was reportedly associated with decreased adherence, unfavorable clinical outcomes and potentially hazardous consequences [99-101]. WHO guideline [69] seems to be a good solution for this problem in which the appropriate place is keeping medicine in enclosed, at a cool or dry place, at an inaccessible place for children.

Medicine package either can influence storage and wastage. According to the literature, there was a positive association between oversized drugs and home storage especially for acute conditions such as pain or nausea and vomiting. Ekedahl et al., proposed a feasible way to decrease the volume of unused medicines in which a small "starter pack" is prescribed whenever a new treatment is initiated. If the consumption stopped, only small volumes would be stocked or discarded [23]. A recent study by Bach et al., has reported 27 to $30 \%$ wastage in $3.5 \mathrm{mg}$ vials of bortezomib compared to $1.5 \mathrm{mg}$ vials [84].

The majority of the studies (72.7\%) highlighted that most countries, did not have any guidelines for disposal of medicines, not only imposes a financial burden on society but also creates environmental hazards through the accumulation of chemical ingredients in landfills and freshwater resources. High-income countries have conducted several schemes for disposal of household's unused medicines which could be adopted as a practical solution for low and middle-income countries. For example, the National Return

Page $11 / 20$ 
and Disposal of Unwanted Medicines (Nat RUM) scheme in Australia which provides a route to return leftover medicines to community pharmacies [73]. Studies in Sweden and Australia suggested a unitary medicine take-over system or educational campaigns at the national level instead of state-run programs [71, 73]. In Nebraska, especial boxes placed in pharmacies that allow consumers to return their medicines to the pharmacy [102]. Arkaravichien et al [103]., and Yang et al [104]., proposed that the national health system can provide financial incentives for pharmacies and households who participate in take-back schemes.

\section{Strengths}

This systematic review focused on the most important part of the consumption chain which is before medicine wastage and its related harms to the environment. Furthermore, most of the home storage was reviewed and reported which we believe our study results can provide evidence for decision-making at individual and community levels.

\section{Limitation of the study}

Since all of the included studies have focused on quantitative analysis of household's medicine storage, then the household's preferences or their experiences as one of key influential factors in triggering inappropriate storage or wastage have not addressed decently. The existing heterogeneity in design and results of included studies hampered pooled estimation and drawing consensus on main related concerns.

\section{Conclusion}

This systematic review gathered evidence from different geographical and demographical settings implies that in-home medicine storage is a worldwide problem that could lead to irrational use, wastage of medicine and hazardous outcomes associated with. Factors beyond medical needs determine medicines storage in studied contexts which urges effective strategies in the supply and demand side of the medicine consumption chain. The first necessary step to mitigate home storage is adequate legislation and strict enforcement of regulations on dispensing, prescription and marketing of medicines. Also, proper educational interventions targeting both health professionals and community members could be helpful in this regard. Patients pressure on excessive prescription, irrational storage and use of medicines and inappropriate disposal practices deserve efficient community centered programs for increasing awareness of these issues. The current data suggests that in low- and middle-income countries health systems should necessarily pay more attention to setting medicine return back programs to prevent environmental hazardous impacts of improper disposal of wasted medications.

\section{Abbreviations}

WHO: World Health Organization; ATC: Anatomical Therapeutic Chemical; DDD: Daily Dose Defined; N: Nervous system; J: Antiinfective for systemic use; A: Alimentary tract drug; B: Blood and blood forming organs; C: Cardiovascular system; R: Respiratory system; M: musculoskeletal system; P: Antiparasitic products, insecticides and repellents; D: Dermatological agents; UOR: unadjusted odds ratio Odd Ratio; AOR: adjusted odds ratio; GIT: Gastrointestinal tract; NSAIDs: Non-steroidal anti-inflammatory drugs.

\section{Declarations}

\section{Ethics approval and consent to participate}

This study does not include any animal or human participants. Ethics approval and consent to participate are not applicable.

\section{Consent for publication}

Not applicable.

\section{Availability of data and materials}

All data generated or analysed during this study are included in this published article (and its supplementary information files). 
The authors declare that they have no competing interests.

\section{Funding}

The research project was sponsored and funded by Tabriz University of Medical Sciences.

\section{Authors' contribution}

AM and $A J$ conceived the study. AM, AJ, and MN selected the studies. AM and AJ extracted the data, and independently decided for inclusion or exclusion, and in events of disagreement, MN helped to resolve. AM, AJ, MY and KD performed all the statistical analyses. AM and AJ wrote the initial manuscript. MN, MY, and KD contributed to the revision of the manuscript. All authors read and approved the final manuscript.

\section{Acknowledgements}

We thank the Research and Innovation Chancellor, Tabriz University of Medical Sciences for supporting this work.

\section{Authors' Information}

${ }^{1}$ Department of Health Economics, School of Management and Medical Informatics, Tabriz University of Medical Sciences, Tabriz, Iran. ${ }^{2}$ Department of Health Economics, Iranian Evidence-Based Medicine Center of Excellence, Tabriz University of Medical Sciences, Tabriz, Iran. ${ }^{3}$ Department of Pharmacology \&Toxicology, Faculty of Pharmacy, Tabriz University of Medical Sciences, Tabriz, Iran. ${ }^{4}$ Iranian Center of Excellence in Health Management, Department of Health Economics, School of Management and Medical Informatics, Tabriz University of Medical Sciences, Tabriz, Iran. ${ }^{5}$ Department of Public Health Sciences, School of Health Sciences, Mid Sweden University, Sundsvall, Sweden. ${ }^{5}$ Higher School of Public Health, Kazakh National University, Almaty, Kazakhstan.

\section{References}

1. Wondimu A, Molla F, Demeke B, Eticha T, Assen A, Abrha S, Melkam W. Household storage of medicines and associated factors in Tigray Region, Northern Ethiopia. PLoS One 2015, 10(8).

2. Hussain R, Rashidian A, Hafeez A. A SURVEY ON HOUSEHOLD STORAGE OF MEDICINES IN PUNJAB, PAKISTAN. Journal of Ayub Medical College Abbottabad. 2019;31(1):90-7.

3. Jassim A-M. In-home drug storage and self-medication with antimicrobial drugs in Basrah, Iraq. Oman Medical Journal. 2010;25(2):79.

4. Narwat A, Sindhu A. Practice towards disposal of medicines (unused/expired drugs) among the patients visiting tertiary care teaching hospital in Haryana, India. International Journal of Research in Medical Sciences. 2019;7(8):3050.

5. Bashaar M, Thawani V, Hassali MA, Saleem F. Disposal practices of unused and expired pharmaceuticals among general public in Kabul. BMC Public Health. 2017;17(1):45.

6. De Bolle L, Mehuys E, Adriaens E, Remon J-P, Van Bortel L, Christiaens T. Home medication cabinets and self-medication: a source of potential health threats? Ann Pharmacother. 2008;42(4):572-9.

7. Organization WH. Regional Office for South-East Asia. (2011). Promoting rational use of medicines. WHO Regional Office for South-East Asia. https://apps. who.int/iris/handle/10665/205688.

8. Bennadi D. Self-medication: A current challenge. Journal of basic clinical pharmacy. 2013;5(1):19.

9. Patil SB, Vardhamane SH, Patil BV, Santoshkumar J, Binjawadgi AS, Kanaki AR. Self-medication practice and perceptions among undergraduate medical students: a cross-sectional study. Journal of clinical diagnostic research: JCDR. 2014;8(12):HC20.

10. Daughton CG, Ruhoy IS. The afterlife of drugs and the role of pharmecovigilance. Drug Saf. 2008;31(12):1069-82.

11. Akici A, Oktay S. Rational pharmacotherapy and pharmacovigilance. Current drug safety. 2007;2(1):65-9.

12. Sultana J, Cutroneo P, Trifirò G. Clinical and economic burden of adverse drug reactions. Journal of pharmacology pharmacotherapeutics. 2013;4(Suppl1):73. 
13. Sanford CP. An unrelenting epidemic of deaths from prescription drugs in North Carolina. In: 2008: 4-7.

14. Kheir N, El Hajj MS, Wilbur K, Kaissi RML, Yousif A. An exploratory study on medications in Qatar homes. Drug Healthc Patient Saf. 2011;3:99.

15. Martins RR, Farias AD, Oliveira YMdC, Diniz RdS, Oliveira AG. Prevalence and risk factors of inadequate medicine home storage: a community-based study. Revista de saude publica. 2017;51:95.

16. Ross-Durow PL, McCabe SE, Boyd CJ. Adolescents' access to their own prescription medications in the home. J Adolesc Health. 2013;53(2):260-4.

17. Siler S, Duda S, Brown R, Gbemudu J, Weier S, Glaudemans J: Safe Disposal of Unused Controlled Substances. King Pharmaceuticals Retrieved from 2009.

18. James TH, Helms ML, Braund R. Analysis of medications returned to community pharmacies. Ann Pharmacother. 2009;43(10):1631-5.

19. Ocan M, Bbosa GS, Waako P, Ogwal-Okeng J, Obua C. Factors predicting home storage of medicines in Northern Uganda. BMC Public Health. 2014;14(1):650.

20. Ruhoy IS, Daughton CG. Beyond the medicine cabinet: An analysis of where and why medications accumulate. Environment international. 2008;34(8):1157-69.

21. Abou-Auda HS. An economic assessment of the extent of medication use and wastage among families in Saudi Arabia and Arabian Gulf countries. Clinical therapeutics. 2003;25(4):1276-92.

22. Sweileh WM, Sawalha AF, Zyoud SH, Al-Jabi SW, Bani Shamseh FF, Khalaf HS. Storage, utilization and cost of drug products in Palestinian households. Int J Clin Pharmacol Ther. 2010;48(1):59.

23. Ekedahl ABE. Reasons why medicines are returned to Swedish pharmacies unused. Pharmacy world science. 2006;28(6):352-8.

24. Dayom DW, Enato EFO, Mantim N, Dangiwa DA. EXPIRED AND LEFTOVER MEDICINES IN THE HOME: POTENTIALS FOR ACCIDENTAL DRUG POISONING IN CHILDREN 2014, 5(4):283-288.

25. Temu MJ, Kaale E, Marawiti M. Storage of antimalarials at household level and associated factors in Kiromo ward, Bagamoyo Tanzania. Afr Health Sci. 2006;6(1):43-8.

26. Mirza N, Ganguly B. Utilization of medicines available at home by general population of rural and urban set up of Western India. Journal of clinical diagnostic research: JCDR. 2016;10(8):FC05.

27. Annear B, Sinclair K, Robbe IJ. Response to 'Returned medicines: waste or a wasted opportunity?'. Journal of public health. 2008;30(2):209-9.

28. West LM, Diack L, Cordina M, Stewart D. A cross-sectional survey of the Maltese general public on medication wastage. International journal of clinical pharmacy. 2016;38(2):261-70.

29. Ocan M, Obuku EA, Bwanga F, Akena D, Richard S, Ogwal-Okeng J, Obua C. Household antimicrobial self-medication: a systematic review and meta-analysis of the burden, risk factors and outcomes in developing countries. BMC Public Health. 2015;15(1):742.

30. Shaghaghi A, Asadi M, Allahverdipour H. Predictors of self-medication behavior: a systematic review. Iranian journal of public health. 2014;43(2):136.

31. Azami-Aghdash S, Mohseni M, Etemadi M, Royani S, Moosavi A, Nakhaee M. Prevalence and cause of self-medication in Iran: a systematic review and meta-analysis article. Iranian journal of public health. 2015;44(12):1580.

32. Alhomoud F, Aljamea Z, Almahasnah R, Alkhalifah K, Basalelah L, Alhomoud FK. Self-medication and self-prescription with antibiotics in the Middle East-do they really happen? A systematic review of the prevalence, possible reasons, and outcomes. International journal of infectious diseases. 2017;57:3-12.

33. Gualano MR, Bert F, Passi S, Stillo M, Galis V, Manzoli L, Siliquini R. Use of self-medication among adolescents: a systematic review and meta-analysis. The European Journal of Public Health. 2015;25(3):444-50.

34. Ayalew MB. Self-medication practice in Ethiopia: a systematic review. Patient Prefer Adherence. 2017;11:401.

35. Nepal G, Bhatta S. Self-medication with antibiotics in WHO Southeast Asian Region: a systematic review. Cureus. 2018;10(4):e2428. 
36. Limaye D, Limaye V, Krause G, Fortwengel G. A systematic review of the literature to assess self-medication practices. Annals of Medical Health Sciences Research. 2017;7:1-15.

37. West LM, Diack L, Cordina M, Stewart D. A systematic review of the literature on 'medication wastage': an exploration of causative factors and effect of interventions. International journal of clinical pharmacy. 2014;36(5):873-81.

38. Makki M, Hassali MA, Awaisu A, Hashmi F. The Prevalence of Unused Medications in Homes. Pharmacy. 2019;7(2):61.

39. Kusturica MP, Tomas A, Sabo A: Disposal of unused drugs: Knowledge and behavior among people around the world. In: Reviews of Environmental Contamination and Toxicology Volume 240. edn.: Springer; 2016: 71-104.

40. Tong AYC, Peake BM, Braund R. Disposal practices for unused medications around the world. Environment international. 2011;37(1):292-8.

41. Hussain A, Malik M, Iram R. Medicine storage trends \& practices: a literature review. J App Pharm. 2017;9:01-14.

42. Organization WH: Guidelines for ATC classification and DDD assignment [Internet]. Oslo: WHO Collaborating Centre for Drug Statistics Methodology 2018.

https://www.drugsandalcohol.ie/29364/1/WHO\%20Collaborating\%20Centre\%20for\%20Drug\%20Statistics\%20Methodology.pdf.

43. Moher D, Liberati A, Tetzlaff J, Altman DG, Group P. Preferred reporting items for systematic reviews and meta-analyses: the PRISMA statement. PLoS med. 2009;6(7):e1000097.

44. Tsiligianni IG, Delgatty C, Alegakis A, Lionis C. A household survey on the extent of home medication storage. A cross-sectional study from rural Crete, Greece. Eur J Gen Pract. 2012;18(1):3-8.

45. Al-Azzam S, Khader Y, Rawashdeh S, Hijazi S. An assessment of the Extent of Medication Wastage among Families in Jordan. Jordan J Pharm Sci. 2012;5(1):65-73.

46. Wongpoowarak P, Wanakamanee U, Panpongtham K, Trisdikoon P, Wongpoowarak W, Ngorsuraches S. Unused medications at home-reasons and costs. Int J Pharm Pract. 2004;12(3):141-8.

47. Dadgarmoghaddam M, Imenshahidi M, Aliabadi A, Baseri H, Khajedaluee M. Unused Medicines in Households. Razavi International Journal of Medicine. 2016;4(1):e34351.

48. Aljinović-Vučić V, Trkulja V, Lacković Z. Content of home pharmacies and self-medication practices in households of pharmacy and medical students in Zagreb, Croatia: findings in 2001 with a reference to 1977. Croatian Medical Journal. 2005;46(1):7480.

49. Schenkel EP, Fernandes LC, Mengue SS. Como são armazenados os medicamentos nos domicílios? acta farmacéutica bonaerense. 2005;24(2):266.

50. Beckhauser GC, Valgas C, Galato D. Perfil do estoque domiciliar de medicamentos em residências com crianças. Revista de Ciências Farmacêuticas Básica e Aplicada. 2013;33(4):583-9.

51. Paut Kusturica M, Tomić Z, Bukumirić Z, Horvat O, Pavlović N, Mikov M, Sabo A. Antibiotics in Serbian Households: a Source of Potential Health and Environmental Threats? Cent Eur J Public Health. 2015;23(2):114-8.

52. McNulty CA, Boyle P, Nichols T, Clappison DP, Davey P. Antimicrobial drugs in the home, United Kingdom. Emerg Infect Dis. 2006;12(10):1523.

53. Garey KW, Johle ML, Behrman K, Neuhauser MM. Economic consequences of unused medications in Houston, Texas. Ann Pharmacother. 2004;38(7-8):1165-8.

54. Vellinga A, Cormican S, Driscoll J, Furey M, O'Sullivan M, Cormican M. Public practice regarding disposal of unused medicines in Ireland. Sci Total Environ. 2014;478:98-102.

55. Kusturica MP, Sabo A, Tomic Z, Horvat O, Šolak Z. Storage and disposal of unused medications: knowledge, behavior, and attitudes among Serbian people. International journal of clinical pharmacy. 2012;34(4):604-10.

56. Zargarzadeh AH, Tavakoli N, Hassanzadeh A. A survey on the extent of medication storage and wastage in urban Iranian households. Clinical therapeutics. 2005;27(6):970-8.

57. Banwat SB, Auta A, Dayom DW, Buba Z. Assessment of the storage and disposal of medicines in some homes in Jos north local government area of Plateau State, Nigeria. Tropical Journal of Pharmaceutical Research. 2016;15(5):989-93.

58. Deviprasad PS, Laxman CV. Cross sectional study of factors associated with home storage of medicines. J Chem Pharm Res. 2016;8(8):1114-20. 
59. Yousif MA. In-home drug storage and utilization habits: a Sudanese study. 2002, 8(2-3):422-431.

60. Teni FS, Surur AS, Belay A, Wondimsigegn D, Gelayee DA, Shewamene Z, Legesse B, Birru EM. A household survey of medicine storage practices in Gondar town, northwestern Ethiopia. BMC Public Health. 2017;17(1):238.

61. Abushanab AS, Sweileh WM, Wazaify M. Storage and wastage of drug products in J ordanian households: a cross-sectional survey. Int J Pharm Pract. 2013;21(3):185-91.

62. Gitawati R. Pattern of household drug storage. Kesmas: National Public Health Journal. 2014;9(1):27-31.

63. Gupta J, Alam N, Bhardwaj A, Amin F. Prospective survey study on assessment and education of home medicine cabinet in general population of community. International Journal of Pharmaceutical Sciences Research. 2011;2(5):1237.

64. Temu-Justin M, Risha PG, Mlavwasi YG, Makwaya C, Leshabari MT. Availability and Usage of Drugs at Household Level i Tanzania: Case Study in Kinondoni District, Dar es Salaam. East Central African Journal of Pharmaceutical Sciences. 2002;5(3):49-54.

65. Kumar YS, Raja SW, Sunitha J, Azharuddin S, Ganesh Raj PC, Raj SB, Reddy KB. Household survey on rational use of medicines in India. International Journal of Pharmacy Therapeutics. 2013;4(1):59-69.

66. Kusturica MP, Tomas A, Tomic Z, Bukumiric D, Corac A, Horvat O, Sabo A. Analysis of expired medications in Serbian households. Slovenian Journal of Public Health. 2016;55(3):195-201.

67. Ristić G, Đorđević A, Hristov S. A regional model for household pharmaceutical waste management. In: 2016: Thomas Telford Ltd: 191-199.

68. Sooksriwong C-o, Jarupas C, Chinawong D, Supakul S, Ploylermsang C, Sornlumlertwanich K, Janto S. Values of leftover drugs in households: preliminary study in 5 major Thai cities. Journal of Asian Association of Schools of Pharmacy. 2013;2:235-42.

69. Organization WH: Annex 9: Guide to good storage practices for pharmaceuticals. WHO Technical Report Series 2003. https://www.who.int/medicines/areas/quality_safety/quality_assurance/GuideGoodStoragePracticesTRS908Annex9.pdf?ua=1.

70. Glassmeyer ST, Hinchey EK, Boehme SE, Daughton CG, Ruhoy IS, Conerly O, Daniels RL, Lauer L, McCarthy M, Nettesheim TG. Disposal practices for unwanted residential medications in the United States. Environment international. 2009;35(3):566-72.

71. Persson M, Sabelström E, Gunnarsson B. Handling of unused prescription drugs-knowledge, behaviour and attitude among Swedish people. Environment international. 2009;35(5):771-4.

72. Lubick N. Drugs in the environment: do pharmaceutical take-back programs make a difference? In: National Institute of Environmental Health Sciences. 2010;118(5):A210.

73. Wheeler AJ, Spinks J, Bettington E, Kelly F. Evaluation of the National Return of unwanted medicines (RUM) program in Australia: a study protocol. Journal of pharmaceutical policy practice. 2017;10(1):38.

74. Hwang B-D. Storage and disposal of unused medications for housewives in the Busan Metropolitan City. The Korean Journal of Health Service Management. 2013;7(2):69-79.

75. Braund R, Gn G, Matthews R. Investigating unused medications in New Zealand. Pharmacy world science. 2009;31(6):664.

76. Vogler S, Leopold C, Zuidberg C, Habl C. Medicines discarded in household garbage: analysis of a pharmaceutical waste sample in Vienna. Journal of pharmaceutical policy practice. 2014;7(1):6.

77. Vogler S, de Rooij RHPF. Medication wasted-Contents and costs of medicines ending up in household garbage. Research in Social Administrative Pharmacy. 2018;14(12):1140-6.

78. Gracia-Vásquez SL, Ramírez-Lara E, Camacho-Mora IA, Cantú-Cárdenas LG, Gracia-Vásquez YA, Esquivel-Ferriño PC, RamírezCabrera MA, Gonzalez-Barranco P. An analysis of unused and expired medications in Mexican households. International journal of clinical pharmacy. 2015;37(1):121-6.

79. Sharif SI, Abduelkarem AR, Bustami HA, Haddad LI, Khalil DS. Trends of home drug storage and use in different regions across the northern United Arab Emirates. Medical Principles Practice. 2010;19(5):355-8.

80. Hu J, Wang Z. In-home antibiotic storage among Australian Chinese migrants. International Journal of Infectious Diseases. 2014;26:103-6.

81. Norris P, Ng LF, Kershaw V, Hanna F, Wong A, Talekar M, Oh J, Azer M, Cheong L. Knowledge and reported use of antibiotics amongst immigrant ethnic groups in New Zealand. J Immigr Minor Health. 2010;12(1):107. 
82. Kelly F, McMillan S, Spinks J, Bettington E, Wheeler AJ. 'You don't throw these things out:'an exploration of medicines retention and disposal practices in Australian homes. BMC Public Health. 2018;18(1):1026.

83. Bekker CL, Van Den Bemt BJF, Egberts ACG, Bouvy ML, Gardarsdottir H. Patient and medication factors associated with preventable medication waste and possibilities for redispensing. International journal of clinical pharmacy. 2018;40(3):704-11.

84. Bach PB, Conti RM, Muller RJ, Schnorr GC, Saltz LB. Overspending driven by oversized single dose vials of cancer drugs. Bmj. 2016;352:i788.

85. Gunnell D, Hawton K, Murray V, Garnier R, Bismuth C, Fagg J, Simkin S. Use of paracetamol for suicide and non-fatal poisoning in the UK and France: are restrictions on availability justified? Journal of Epidemiology Community Health. 1997;51(2):175-9.

86. Hawton K, Bergen H, Simkin S, Dodd S, Pocock P, Bernal W, Gunnell D, Kapur N. Long term effect of reduced pack sizes of paracetamol on poisoning deaths and liver transplant activity in England and Wales: interrupted time series analyses. Bmj. 2013;346:f403.

87. Nourjah P, Ahmad SR, Karwoski C, Willy M. Estimates of acetaminophen (paracetomal)-associated overdoses in the United States. Pharmacoepidemiol Drug Saf. 2006;15(6):398-405.

88. Kusturica MP, Tomic Z, Bukumiric Z, Ninkovic L, Tomas A, Stilinovic N, Sabo A. Home pharmacies in Serbia: an insight into selfmedication practice. International journal of clinical pharmacy. 2015;37(2):373-8.

89. Grigoryan L, Burgerhof JGM, Degener JE, Deschepper R, Lundborg CS, Monnet DL, Scicluna EA, Birkin J, Haaijer-Ruskamp FM. Determinants of self-medication with antibiotics in Europe: the impact of beliefs, country wealth and the healthcare system. $J$ Antimicrob Chemother. 2008;61(5):1172-9.

90. Saradamma RD, Higginbotham N, Nichter M. Social factors influencing the acquisition of antibiotics without prescription in Kerala State, south India. Soc Sci Med. 2000;50(6):891-903.

91. Jakovljevic MB. Resource allocation strategies in Southeastern European health policy. In: Springer. 2013;14(2):153-9.

92. Byarugaba DK. Antimicrobial resistance in developing countries and responsible risk factors. Int J Antimicrob Agents. 2004;24(2):105-10.

93. Sawair FA, Baqain ZH, Karaky AA, Eid RA. Assessment of self-medication of antibiotics in a Jordanian population. Medical Principles Practice. 2009;18(1):21-5.

94. Beyene K, Aspden T, Sheridan J. Prevalence and predictors of medicine saving and future prescription medicine sharing: findings from a New Zealand online survey. Int J Pharm Pract. 2019;27(2):166-74.

95. Daban F, Pasarín MI, Rodríguez-Sanz M, García-Altés A, Villalbí JR, Zara C, Borrell C. Social determinants of prescribed and nonprescribed medicine use. Int J Equity Health. 2010;9(1):12.

96. Putignano D, Bruzzese D, Orlando V, Fiorentino D, Tettamanti A, Menditto E. Differences in drug use between men and women: an Italian cross sectional study. BMC Womens Health. 2017;17(1):73.

97. Loikas D, Wettermark B, von Euler M, Bergman U, Schenck-Gustafsson K. Differences in drug utilisation between men and women: a cross-sectional analysis of all dispensed drugs in Sweden. BMJ open. 2013;3(5):e002378.

98. Chowdhury N, Matin F, Chowdhury SFUA. Medication taking behavior of students attending a private university in Bangladesh. In: De Gruyter. 2009;21(3):361-70.

99. Sorensen L, Stokes JA, Purdie DM, Woodward M, Roberts MS. Medication management at home: medication-related risk factors associated with poor health outcomes. Age Ageing. 2005;34(6):626-32.

100. Stanisz B, Regulska K. Kinetics of degradation of imidapril hydrochloride in finished dosage formulations. Acta Pol Pharm. 2013;70(4):737-42.

101. Özdemir R, Bayrakci B, Teksam Ö, Yalçin B, Kale G. Thirty-three-year experience on childhood poisoning. Turk J Pediatr. 2012;54(3):251.

102. Lamb A. Pharmacists' Role in Safe and Legal Medication Disposal. 2012.

103. Arkaravichien W, Ruchipiyarak T, Thawinwan W, Benjawilaikul S: A Threat to the Environment from Practice of Drug Disposal in Thailand. EnvironmentAsia 2014, 7(1):13-8.

104. Yang SL, Tan SL, Goh QL, Liau SY. Utilization of ministry of health medication return programme, knowledge and disposal practice of unused medication in Malaysia. J Pharm Pract Commun Med. 2018;4:1-3. 


\section{Figures}

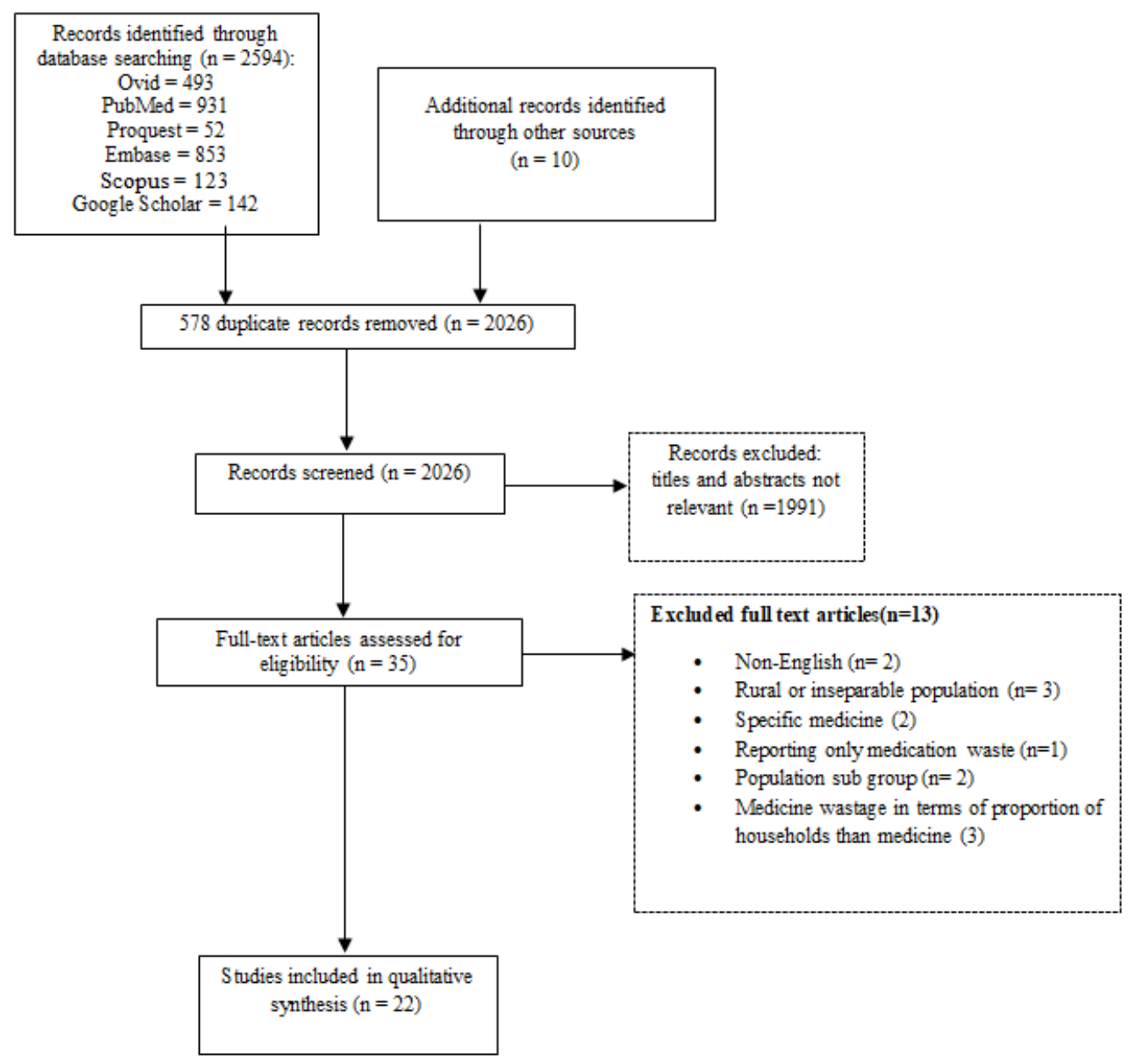

\section{Figure 1}

PRISMA Chart describing systematic review search process 


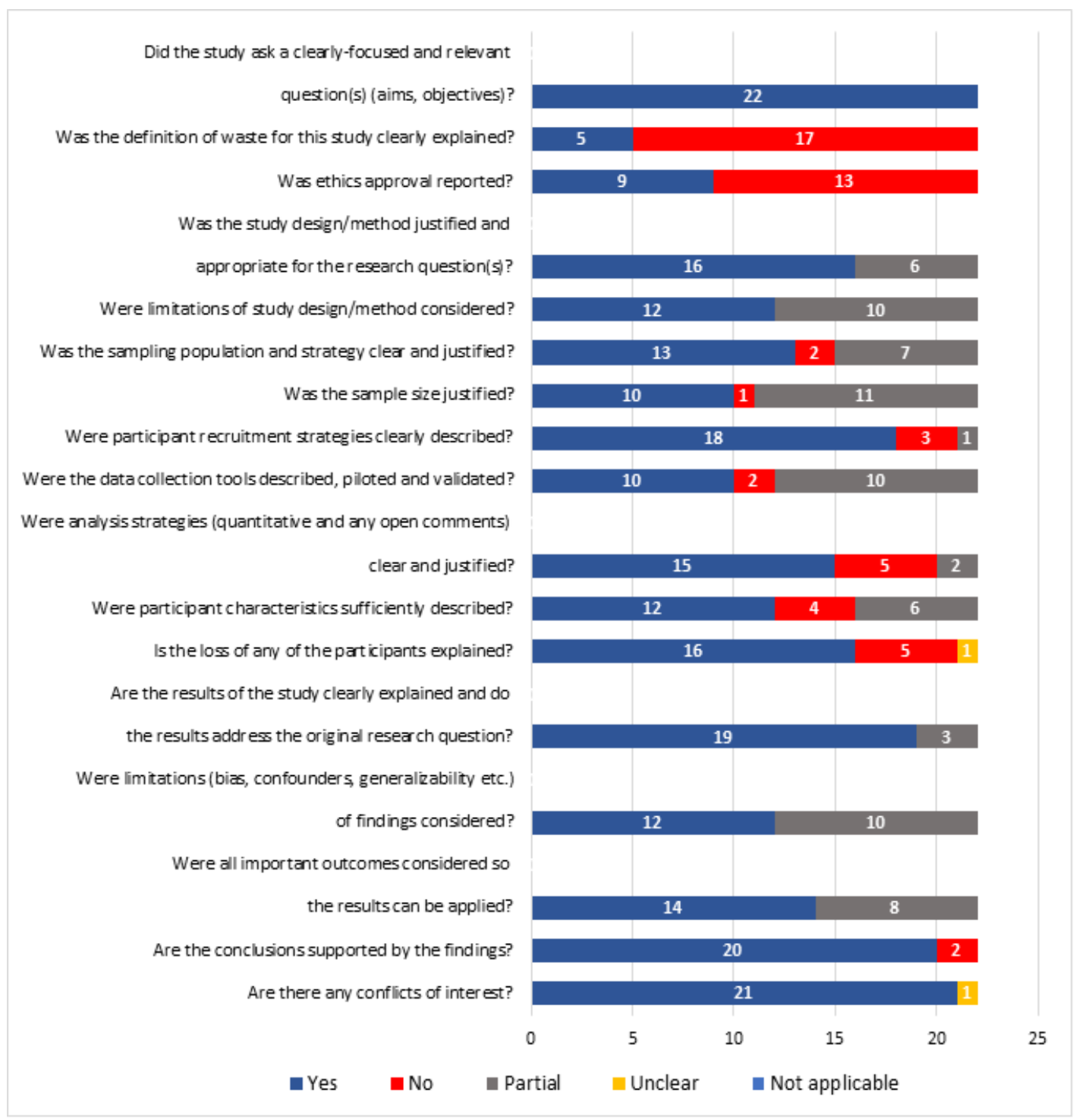

Figure 2

Stacked bar chart describing the methodological quality as captured by the quality assessment tool.

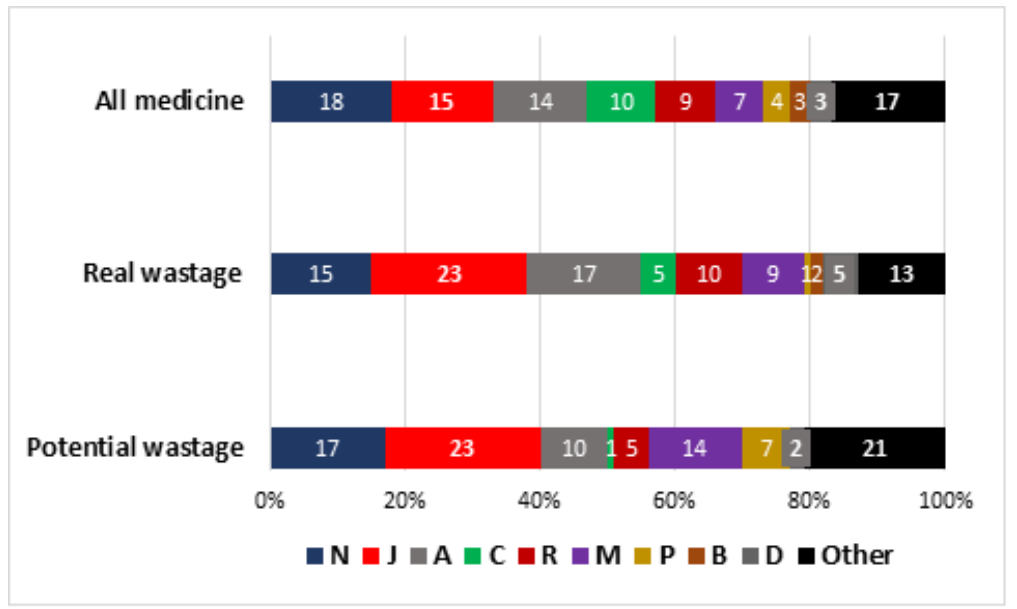

Figure 3 


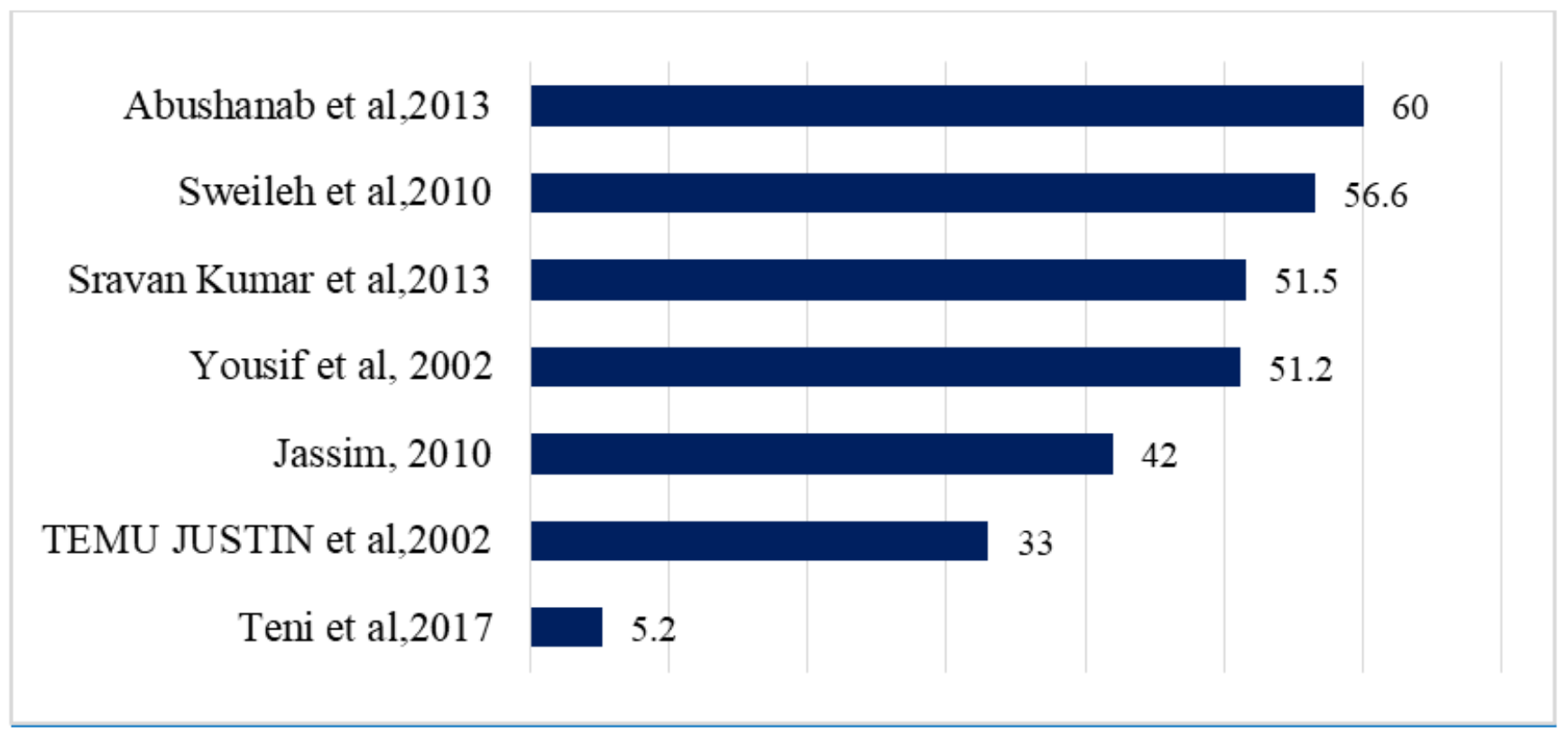

Figure 4

Appropriate storage conditions (\% medicine)

\section{Supplementary Files}

This is a list of supplementary files associated with this preprint. Click to download.

- Additionalfile7.docx

- Additionalfile6.docx

- Additionalfile3.docx

- Additionalfile2.docx

- Additionalfile5.docx

- Additionalfile4.docx

- Additionalfile1.doc 